\title{
Влияние скорости роста на состав слоев в подрешетке пятой группы при МЛЭ твердых растворов InAsSb
}

\author{
Е.А. Емельянов, М.О. Петрушков, А.В. Васев, Б.Р. Семягин, М.А. Путято, И.Д. Лошкарев, \\ В.В. Преображенский \\ Институт физики полупроводников им. А.В.Ржанова СО РАН, \\ Новосибирск, 630090, пр. Ак. Лаврентьева, 13 \\ тел: (383)333-19-67, факс: (383)333-75-02, эл. почта: е2a@isp.nsc.ru
}

DOI 10.34077/RCSP2019-22

Твёрдые растворы $\operatorname{InA} s_{x} S b_{1-x}$ являются перспективными полупроводниковыми материалами для создания быстродействующих электронных и оптоэлектронных приборов, работающих в инфракрасной области спектра. Выращивание таких твердых растворов с заданным составом является сложной научно-технологической задачей. Это обусловлено тем, что состав $\operatorname{In} A s_{x} S b_{1-x}$ в подрешётке пятой группы является сложной функцией условий роста, таких как температура роста $\left(T_{\mathrm{s}}\right)$, величины и соотношения потоков атомов индия $\left(J_{I I I}\right)$, молекул мышьяка $\left(J_{A s}\right)$ и сурьмы $\left(J_{S b}\right)[1]$.

Целью данной работы было экспериментальное исследование влияния скорости роста (как самостоятельного параметра) на состав твёрдых растворов $I n A s_{x} S b_{1-x}$ при молекулярно-лучевой эпитаксии. Для этого необходимо в процессе роста образцов фиксировались как соотношение потоков V группы - $J_{S b} / J_{A s}$, так и соотношение полных потоков III и $\mathrm{V}$ групп - $\left(J_{S b}+J_{A s}\right) / J_{I I I}$.

На подложках $\mathrm{GaAs}(100)$ была выращена серия из четырех образцов $\operatorname{InAs} S s_{x-x}$ с использованием потоков молекул $\mathrm{As}_{2}$ и $\mathrm{Sb}_{4}$ при $T_{\mathrm{s}}=380^{\circ} \mathrm{C}$. Скорость роста $\left(V_{g}\right)$ варьировалась в диапазоне от 0.25 до 2 монослоев в секунду. Выращенные образцы были исследованы методом высокоразрешающей рентгеновской дифрактометрии.

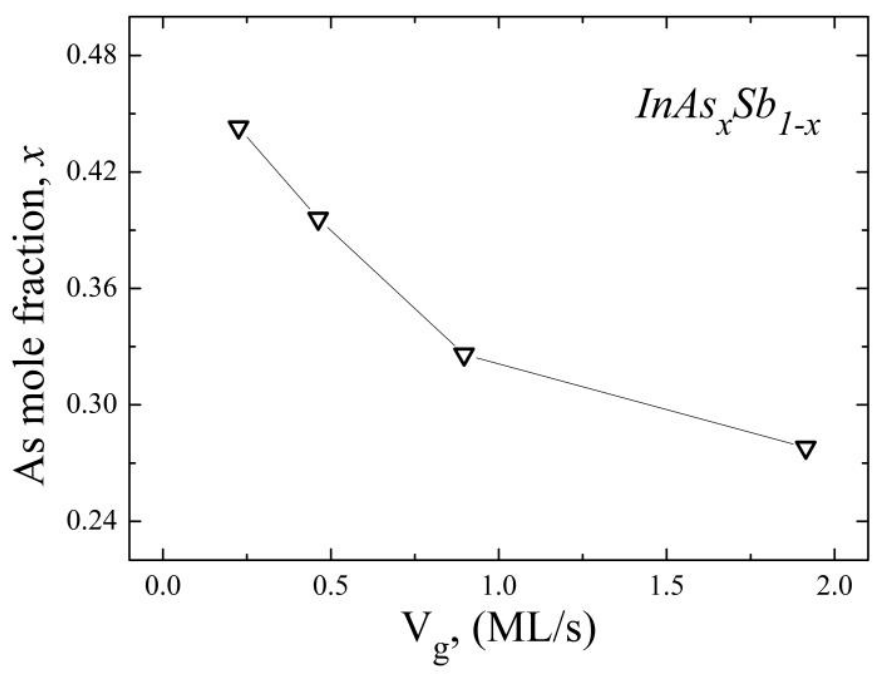

Полученная зависимость состава $x$ твёрдого раствора $I n A s_{x} S b_{1-x}$ от $V_{g}$ приведена на рисунке. Согласно приведенным данным, скорость роста выступает самостоятельным параметром процесса эпитаксии, определяющим состав твёрдых растворов с замещением по пятой группе.

В работах $[1,2]$ сообщается о факте влияния скорости роста на состав твердых растворов $A^{I I I} A s S b$. Но важно отметить, что фиксируя значение $J_{S b} / J_{A s}$, авторы не поддерживали постоянным соотношение $\left(J_{S b}+J_{A s}\right) / J_{I I I}$ при варьировании $V_{g}$. При таком подходе не учитывается влияние соотношения $\left(J_{S b}+J_{A s}\right) / J_{I I I}$ на состав адсорбционных слоев на поверхности роста. Поэтому, по результатам этих работ нельзя прийти к заключению о роли скорости роста, как самостоятельного параметра процессов формирования состава твердых растворов.

В представленной работе обсуждаются механизмы влияния $V_{g}$ на состав твёрдых растворов

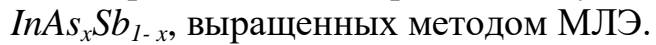

Работа выполнена в рамках ГЗ 0306-2016-0011, 0306-2018-0011 и при поддержке гранта РФФИ 1832-00125.

\section{Лumepamypa}

[1] W. L. Sarney, S.P. Svensson // J. Vac. Sci. Technol B. 2015. V. 33(6). P. 060604-3.

[2] T. Zederbauer, at all. // APL Mater. 2017. V. 5(3). P. 035501-6. 